cation between educators in the United States and East European countries.

Sheilah Mann, APSA's director of educational affairs, is hosting the various delegations at APSA headquarters and sharing information on the civics education projects she coordinates at the Association. Visitors have also been introduced to other services provided by APSA, briefed on APSA's annual meeting, and given complimentary membership to the Association. In addition, the visitors have been briefed on the Association's initiatives regarding scholarly journal donations to Eastern European countries. To date, delegations from Latvia, Poland, and Russia have spent a day at APSA learning about civics education. The others will visit in the near future.

During their time in the United States, the East European visitors are touring American colleges and universities and attending informational sessions on civics education, teaching methodologies, and the American educational system. Their study tours also include visits to congressional offices, embassies, and professional organizations that can provide useful information on developing civics education initiatives.

Also involved in planning these study tours have been political scientists John Patrick of Indiana University's Social Studies Development Center, who hosted the Latvian delegation; Richard Remy of Ohio State's Mershon Center, who hosted the Polish guests; and Stephen Schechter of the Center for Citizenship Education at Russell Sage College in Troy, New York, who hosted the Russian visitors.

\section{Journal Donations to Africa}

Each year the Association donates over 60 subscriptions of the APSR and $P S$ to universities, libraries and other institutions worldwide. The program is maintained in an effort to keep our colleagues abroad abreast of current trends in teaching and research. The donations have been distributed through several programs, including the East and Central European Donation Project and

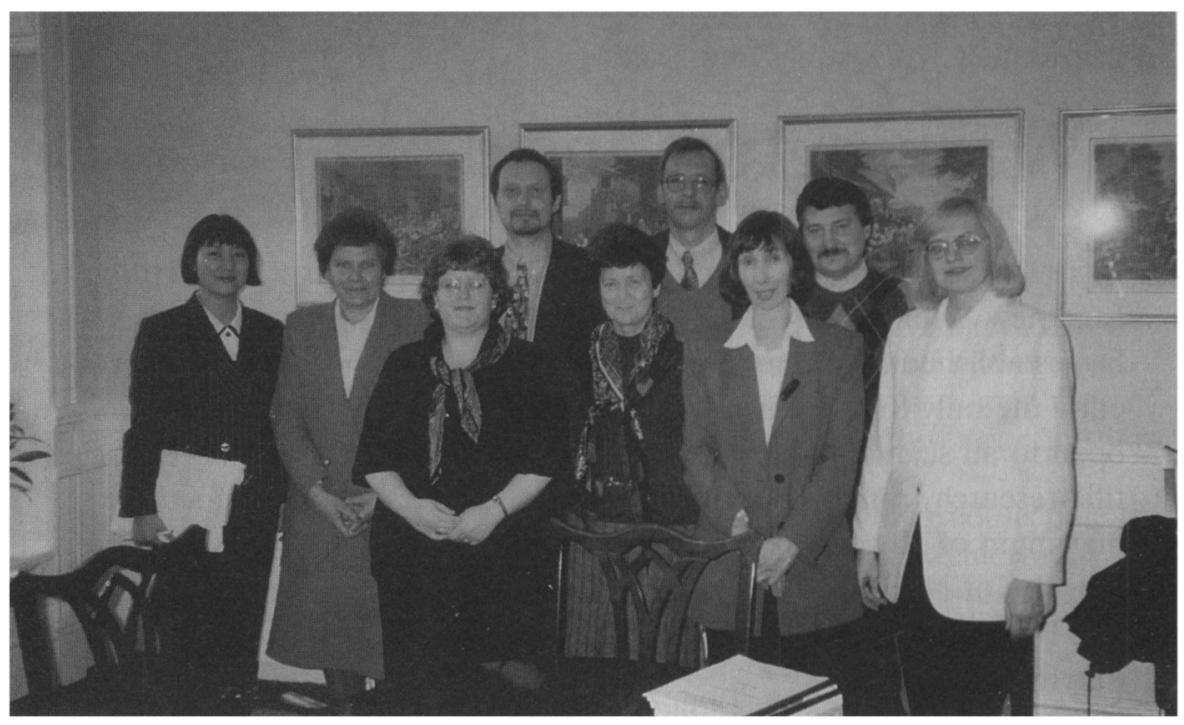

Latvian scholars visit the Association. (1-r) Front row: Jun Yin, APSA Staff Associate; Lolita Spruge, University of Latvia; Candace Boyer, Indiana University; Vija Rudina, Aizkrankle Secondary School; Sheilah Mann, APSA Director of Educational Affairs; Daina Bara, University of Latvia. Back row: Guntars Catlaks, Democracy Advancement Center, Latvia; Valts Sarma, Sala Primary School; Arijs Orlovskis, Liepaja Pedagogical College; and Linda Bara, University of Latvia.

the Sub Saharan Africa Donation Project.

In September 1996, the American Council of Learned Societies and American Association for the Advancement of Science announced the closing of the Sub Saharan Africa Program. At its conclusion the program offered journals from as many as 100 learned societies to nearly 200 universities, libraries, and research centers. An active participant since 1993, the Association has supplied $A P S R$ and $P S$ to 25 locations throughout the region.

Despite the decision of ACLS and AAAS to close this program the Association has stepped forward to

\title{
Minority ID Project Contributors
}

The Minority Identification Project is a collaboration of undergraduate programs and graduate schools encouraging the interest of minority undergraduate students in graduate study in political science. Undergraduate programs recommend promising minority graduate students to APSA which, in turn, gives those names to graduate programs for recruiting purposes.

The following list includes those who have made contributions in the past quarter. The Association thanks all those who made contributions.

Departmental Contributions

Columbia University

Howard University

Johns Hopkins University

Miami University

University of Michigan

Northwestern University

University of Washington

\author{
Individual Contributions \\ Joyce A. Baugh \\ Christopher J. Deering \\ Jeff Goodwin \\ Ricardo Sucre Meredia \\ Terry L. Miller \\ Wilbur C. Rich \\ Debra J. Salazar \\ Joseph M. Schwartz \\ Rogers M. Smith
}


continue delivery of journals to interested institutions. Initial efforts to contact the 25 departments and libraries receiving Association publications has let to positive responses from libraries in Zimbabwe, Senegal, Kenya, and Ethiopia who are interested in continued shipment. The Association hopes to be in contact with a number of the other institutions in the near future.

\section{Travel Grants for 1997 Annual Meeting}

The Association will again offer a limited number of travel grants for graduate students to attend the 1997 Annual Meeting in Washington, DC. Funded through the generosity of APSA members, the maximum award for any grant will be $\$ 300$. Grant will be awarded in two categories: (1) Foreign graduate students attending US institutions and (2) Advanced American graduate students.

Applicants must complete a short application available from the APSA National Office and are required to have a letter of support prepared by their department chair. Applicants without a letter of support will not be considered.

The deadline for recipient of the complete application is July 5. Application forms and further information are available by contacting Sean Twombly at twombly@aspanet.org.

\section{APSA Surveys Political Scientists about Job Placement}

The National Science Foundation is funding a collaborative effort with APSA to collect information about job placement among newly-minted Ph.D.s and ABDs in political science. This project involves the placement class of 1995-96 and is designed to provide insight into how graduate departments and APSA can better inform and assist political scientists in their search for jobs. Surveys were mailed out in the fall of 1996 .

Once the data is gathered and an- alyzed, APSA is planning to publish the findings in $P S$ and conduct a session on placement at the 1998 Annual Meeting in Boston.

In addition to funding the survey for political science, NSF has collaborated with the professional associations of chemistry, geology, mathematics, computer science, and psychology to gather information on placement. Next year, NSF plans to include new Ph.D.s and ABDs in economics, sociology, engineering, and microbiology.

\section{Maynes Assumes Presidency of the Eurasia Foundation}

Charles William Maynes, Editor of Foreign Policy and former APSA Congressional Fellow, was recently named President of the Eurasia Foundation. Maynes replaces Ambassador Thomas Pickering who has been nominated to the position of Undersecretary of State for Political Affairs.

In the course of his career, Maynes has held a number of posts in both the public and private sector. A graduate of Harvard College and a Rhodes Scholar at Oxford University, he entered the Foreign Service in 1962, where he had successive assignments in UN Political Affairs, the US Aid Mission in Laos, and the Economic Section in the American Embassy in Moscow.

In 1970 Maynes was awarded a Congressional Fellowship by the ASPA and worked for Congressman F. Bradford Morse (R-MA) and Senator Fred R. Harris, (D-OK). In

\section{Correction:}

The following dissertation listing is a corrected version of the one published in the December issue of PS:

Miriam Fendius Elman: B.A., Hebrew University, 1988; M.Phil, Columbia, 1993; Ph.D., Ibid., 1996. When the Weak Go to War: Domestic Institutional Choices and Their Foreign Policy Legacies. Columbia.
1972 he became head of the New York Office of the Carnegie Endowment for International Peace and in 1974 became its secretary, the second highest position in the Institution. After an appointment by President Carter as Assistant Secretary for International Organization Affairs in 1977 he assumed editorship of Foreign Policy in 1980.

Established in 1993 with a major grant from USAID to promote democracy and free markets in the New Independent States of the former Soviet Union, the Eurasia Foundation maintains its offices in the APSA building.

\section{Ralph Bunche Institute Participants Selected}

Fifteen outstanding African American students have been selected to participate in the 11th Ralph Bunche Summer Institute. The 1997 Institute will be held on the historic grounds of the University of Virginia on June 8-July 10, 1997. The Institute is designed to introduce promising African American students to the world of graduate study and encourage application to $\mathrm{Ph} . \mathrm{D}$. programs.

The Institute includes two transferable credit courses: quantitative analysis and race and American politics. In addition, guest lecturers and recruiters from Ph.D. programs, as well as the Educational Testing Service, visit with students. The academic environment is challenging, yet supportive. Students learn skills to be successful in as graduate scholars. Most students who attend the Ralph Bunche Summer Institte excel in their senior year and go on to graduate school, many with full graduate fellowships and teaching assistantships.

1997 participants include:

Jhamed Babatunde-Bey, UCLA Tashna Brightwell, Xavier University Kenita Brown, Xavier University Khalilah Brown, University of Virginia Duane Crooks, University of Miami LaKisha Fields, University of South Carolina Fatima Goss, UCLA Maria Kirby, Harvard University Tiffany Miller, Kent State University Dana Olds, Lincoln University Michael Salmon, University of Miami 